\title{
Family-friendly reform of employment law in the UK: an overstretched flexibility.
}

\author{
Oxana Golynker
}

This paper provides a critical assessment of the family-friendly reform of employment law in the UK. It begins with the analysis of the EU policies on work-life balance as the important context of the reform in the UK. The second part of the paper provides and outline of the family-friendly provisions introduced by the Labour and Coalition Governments between 1997 and 2015 and investigates the rationale behind the reform. The paper questions the consistency of the approach to the familyfriendly reform of employment law adopted by the Labour and Coalition governments. It argues that the economic rationale has underpinned the flexibility aspect of family-friendly agenda in both EU and UK policies. In its final part, the paper analyses the flaws in the regulation of family-friendly entitlements and argues that, without proper incentives and guarantees, the reform is unlikely to provide working parents and carers with a real choice and flexibility.

Key Words: reconciliation of work and family life; shared parental leave; choice and flexibility. Introduction.

Family-friendly reform of employment law in the UK may be described as a child of the Labour Government that has been adopted by the Coalition Government. Ever since the announcement of the Labour Government's family-friendly strategy in the White Paper "Fairness at work" in 1998 (Cm 3968

http://webarchive.nationalarchives.gov.uk/+/http:/www.berr.gov.uk/files/file24436.pdf), a host of family friendly changes were introduced with an emphasis on the flexibility of working arrangements, as a neo-liberal strategy of helping working parents and carers to reconcile their work and family responsibilities. Among them are the introduction of "keep in touch" days, extension of the scope of the right to apply for a variation of contract under s. 80F ERA 1996, and the new right of working fathers to additional paternity leave. In the Consultation on modern workplaces, The Coalition Government decided to go even further and introduce flexible parental leave shared between mothers and fathers and extend the right to request flexible working arrangements to all employees. The new provisions have now become law with the adoption of the Children and families Act 2014 and were introduced in stages during 2014 and 2015. Yet, although the measures are presented by the Coalition government as family-friendly, the disproportionate focus on flexibility of employment arrangements without proper guarantees for the employees (for example, proper rates of pay during shared parental leave) is bound to compromise the positive potential of the reform. At the same time, the element of flexibility is not always consistently represented in the conditions of entitlement as elaborated in the Shared parental leave regulations 2014. 
This paper will analyse family-friendly reform in the UK in the light of the policy background and the role of economic objectives in policy-making at both EU and national levels. The paper will question the consistency of the Labour and Coalition governments approach to the family-friendly reform of employment law. It will argue that the economic rationale has been prominent in the formation of the flexibility aspect of family-friendly agenda in both EU and UK policies. The article will then analyse how the distorted basis of regulation of family-friendly entitlements has created an overstretched flexibility without proper incentives and guarantees of rights, which is unlikely to provide working parents and carers with a real choice and flexibility.

\section{The EU context of family-friendly reform of employment law in the UK.}

At the European Union level, the topic of work-life balance has been on the agenda for quite some time (for the detailed analysis of EU policy in this area, see Caracciolo di Torella and Masselot 2010). As early as 1974 the Social Action Programme (EC Bulletin Supplement $2 / 74$ ) called for the implementation of measures to achieve equality between men and women in the workplace, in particular, with the aim of ensuring that the family responsibilities of all concerned may be reconciled with their job aspirations. The specific focus on reconciliation of work and family life became obvious in the 1990s with the European Council recommendation that the Member States develop or encourage initiatives to enable women and men to reconcile their occupational, family and child-raising responsibilities (Council of the European Union recommendation 92/241/EEC of 31 March 1992 on childcare O.J. [1992] L123/16). The areas of work-life balance identified in the recommendation embraced leave for employed parents, family friendly policies at the workplace, measures to promote increase participation of men in the care and upbringing of children, and childcare services. At this stage, the need for flexibility was not a priority, whereas the emphasis on gender equality could contribute to challenging gender-related stereotypes of parental responsibilities, as was the case in the original Parental leave Directive 96/34 (Directive 96/34/EC O.J. [1996] L145/4). The need for flexibility became pronounced later to serve different policy objectives. Since the late 1990s it has become clear that the EU policy on work-life balance is closely linked to the EU policy of employment management as part of the wider agenda of economic growth and making EU economy more competitive (see further Lewis 2009). As a result, the importance of giving working families choice and flexibility became absorbed in other aspects of managing economy, flexicurity (Communication from the Commission of 27 June 2007 towards common principles of flexicurity: more and better jobs through flexibility and security. $\operatorname{COM}(2007) 359$ final), and European Employment Strategy which was introduced in 1992 by the Treaty of the European Union and now constitutes part of Europe 2020 strategy.

The rhetoric of family-friendly policy in general and flexibility in particular, as a tool for achievement of economic and social objectives, rather than being an objective in itself, as well as viewing families as economic units has dominated the discourse. For example, the Commission's argument in favour of improvement of mothers employment rights emphasised the value of women in the labour market and in maintaining the birth rate. In particular it focused on the studies that showed that measures improving maternity leave, parental leave, 
paternity leave could help increase women's employment rate by 3-4\% (the European Commission MEMO/08/603 of 3 October 2008. http://europa.eu/rapid/press-release_MEMO08-603_en.htm?locale=en). Also, the Commission noted the positive correlation between birth rates and the quality of reconciliation facilities such as child care facilities and flexible working arrangements (the European Commission 2008).

According to Lewis, the Lisbon target for women's employment determined the instrumental approach to work-family reconciliation policies as a tool used to raise women's employment rates, promote adequate security in post-industrial flexible labour markets, resolve the demographic problems, and modernise welfare system (Lewis 2009, p. 13-14). A number of provisions adopted by the EU in the 1990s are pertinent to the objective of reconciling work and family life, some of them with a specific reference to flexibility, such as the Part Time Workers Directive (Council Directive 97/81/EC O.J. [1998] L14/9) and the Fixed term work Directive (Council Directive 99/70/EC O.J. [1999] L175/43), as well as the Working time Directive (Council Directive 93/104/EC O.J. [1994] L307/18). However, the emphasis on the economic aspect resulted in insufficient attention to guaranteeing the conditions of work (Lewis 2009, p. 13). For example, the Part time workers Directive expressly mentions the necessity of introducing measures to facilitate access to part-time work for men and women in order to reconcile professional and family life. The Fixed term work Directive refers to the contribution to the quality of life of the workers and to the improvement of equality of opportunity between women and men. At the same time, the Part time workers Directive does not confer on parents a substantive right to variation of contract, but merely requires employers to give consideration to requests by workers for more family-friendly working arrangements. Taking into account the history of negotiation of the Parental leave Directive 96/34 which took from 1983 until 1996, the choice of soft measures may be understandable, but this does not change the fact that it provides no guarantees.

With the outbreak of the global economic crisis of 2008, it became clear that any progress with measures aimed at enabling parents and carers to have better rights and more choice and flexibility, is now impossible without a political agreement of the Member States and their assessment of the impact of family-friendly measures on the national budget. For example, in December 2010, at a meeting of the EU Employment Council, a large majority of ministers rejected the European Parliament's proposal to legislate for 20 weeks of maternity leave at full pay expressing concerns about the cost implications of extending paid maternity leave. They also rejected plans to include paternity leave in a draft Directive on maternity leave, since the main purpose of the Directive would be to improve the health and safety at work of pregnant women, not to reconcile work, family and private life. The European Parliament's proposal to introduce 2 weeks paternity leave at full pay was also rejected http://www.europarl.europa.eu/sides/getDoc.do?pubRef=-//EP//TEXT+TA+P7-TA-2010$0373+0+\mathrm{DOC}+\mathrm{XML}+\mathrm{V0} / / \mathrm{EN} \# \mathrm{BKMD}-18)$. At the same time measures negotiated and supported by social partners at the EU level were adopted. On 18 June 2009, the European social partners signed a revised Framework agreement increasing the duration of parental leave from 3 to 4 months per parent and introducing the right to ask for a variation of contract on the return from parental leave (flexible working) which was implemented by Directive 2010/18. 
Promotion of equality between men and women continued to be used to support and encourage family-friendly policy and action of the Member States in a new context following the Treaty of Amsterdam. Resolution of 29 June 2000 on balanced participation of women and men in family and working life (O.J. [2000] C218) encouraged the Member States to develop strategies and adopt Government programmes promoting balanced participation of men and women in family and working life as a basic condition of equality under Art. 157 TFEU; to grant working men an individual and non-transferable right to paternity leave to be taken at the same time as the mother takes maternity leave with retention of employment rights; to grant working men rights which are likely to provide support for family life with a view of cementing equality; and to reinforce measures to encourage a balanced sharing between working men and women of the care to be provided for children, elderly, disabled or other dependent persons. Art. 7 of the amended Equal treatment Directive (Directive 2002/73 O.J. [2002] L269/15) mentions the right of Member States to recognise distinct rights to paternity and/or adoption leave. The use of the principle of equal treatment has become more diverse in the context of the need to not only ensure equal participation of women in the employment market, but also spreading the duty of care across to engage both men and women in solving a wide range of social and demographic problems with which the modern welfare state struggles to cope (see also Janssens 2003, p.56; Engelen 2003, p. 273) However Pregnant workers Directive, Equal treatment Directive and Parental leave Directive do not require flexibility of entitlements to respective leave provisions leaving it to the Member States. Moreover, Parental leave Directive asserts non-transferability of parental leave which denies parents the choice. In fact, Parental leave Directive encourages sharing parental responsibilities by providing mothers and fathers with time off, but at the same time, restricts choice and flexibility as to how to use this entitlement. Although seemingly counterintuitive, this approach stems from the focus on two objectives: the need to encourage the return of mothers to employment, and on the promotion of fathers' participation in the upbringing of children (see also Weldon-Johns 2013). However, in combination with the unpaid nature of the leave leading to the low uptake, it is unlikely to be effective in changing gender stereotypes.

Despite the absence of a comprehensive legislative basis for choice and flexibility in familyfriendly employment entitlements at EU level, the jurisdiction of the CJEU provides parents with an opportunity to challenge some of the non-flexible national provisions in law-denying mothers and fathers choice with regard to their compliance with the principle of equal treatment. This was tested in two seminal cases Roca Alvarez (Case C-104/09 Roca Alvarez, Judgment of 30 September 2010) and Montull v INS(Case C-5/12 Montull v INSS, Judgment of 19 September 2013) regarding transferability of maternity leave and the so-called breastfeeding leave from mothers to fathers. In both cases the right to equal treatment for male and female workers was used to contest the refusal to allow the use of the leave by an employed father. The outcome in these cases confirmed that the principle of equal treatment can be successfully used to challenge the rigid national provision of law on leave which precluded transferability of the entitlement from the mother to the father. At the same time, the Montull judgment confirmed the inferior status of father's rights as derived from and dependant on the rights of mothers. Also, transferability of the entitlement from the mother to the father as a single act does not mean that the leave can be used flexibly in other ways, for example in separate blocks or in turns taken by the father and the mother. Therefore, without legislative intervention, the case law of the Court can provide only a limited solution.

Is there any prospect of ending the subordinate position of work life balance measures? The opportunity presented itself when family-friendly provisions became included in the Charter 
of Fundamental Rights of the European Union. However, The Charter has hardly contributed to strengthening the agenda of reconciliation of work and family life which is presented in a patchwork of provisions that are pertinent to the family-friendly objective, but not interconnected in a meaningful way. For example, Art. 23 of the Charter enshrines the principle of equality between men and women. Sometimes, the connection is more complex. Art. 24 proclaims that every child has the right to maintain on a regular basis a personal relationship and direct contact with their parents, unless that is contrary to their interests. In the contemporary environment of full time employment of both parents, this right can be compromised without choice and flexibility that should be offered by family-friendly regulation of employment. Yet, paradoxically, the concept of reconciliation of work and family life is used in the Charter in a very narrow sense in Art. 33 which covers only protection from dismissal for reasons connected with maternity, the right to paid maternity leave and to parental leave following the birth or adoption of a child. The limited scope of intervention of the Union into family-friendly employment policy can be explained by the constraints of the Union competence in this area under Art. 153 TFEU and the principle of subsidiarity. However, even that proved to be too contentious and, among other issues, led to the negotiation of Protocol No 30, according to which the Charter has a limited effect in the UK.

It is also important to note that the impact of the EU law and policy on the family-friendly reform of employment law in the UK may be affected by the outcome of the UK's referendum on membership in the EU which has been pledged by the Conservitive party in their election manifesto and now, with the Conservative government in power, should be held before 2017.

\section{The flexibility agenda in family-friendly policy: from New Labour to the Coalition Government.}

The family-friendly reform of employment law has been inspired by EU initiatives, but has taken on its own character with a prominent emphasis on choice and flexibility, partly in political rhetoric, partly in substance. In the UK, more than in any other Member State of the EU, the model of the male head of the family has consistently informed the entire system of social protection and reconciliation of work and family life is no exception. Family-friendly policy and relevant legal provisions are broadly based on the traditional view of the family and gender roles and relationships (See further Saraceno 2003, p. 238; Segalen 2003, p. 350). As a result, the organisational and practical problems connected with family life have long been regarded in the UK as an essentially a private matter.

The victory of New Labour in 1997 marked a turning point as the Labour Party expressed its commitment to the family-friendly agenda in its Manifesto. In May 1998 the Labour Government published the White Paper Fairness at Work (Cm 3968 http://webarchive.nationalarchives.gov.uk/+/http:/www.berr.gov.uk/files/file24436.pdf) which proclaimed the objective of building a society 'where to be a good parent is not in conflict with being a good employee'. Following the end of opt out of the Social Chapter of the Maastricht Treaty, the Parental Leave Directive was implemented, and the right to parental leave and the right to time off to provide urgent assistance to dependants were introduced by the Employment Act 1999. The right to paid paternity leave, adoption leave, 
and the right to request flexible working variation of contract for parents of children under six were introduced by the Employment Act 2002.

In 2004, the Government published a ten year strategy Choice for Parents, the Best Start for Children in which it set out its long-term vision and identified several important targets: first, that every child gets the best start in life, second, to give parents more choice on how to balance work and family life, and third, to facilitate more equal participation of both mothers and fathers in the upbringing of children. In February 2005 the Government launched a consultation entitled "Work and families: choice and flexibility" leading to the adoption of the Work and families Act 2006 which introduced a number of changes and new entitlements that were either specifically focused on flexibility or enabled flexibility of choice for parents. The Work and families Act 2006 extended the period of maternity pay to 39 weeks; gave unconditional entitlement to 52 weeks of maternity leave; introduced flexibility of return to work after maternity leave with 8 weeks notice (para.2A reg.11 of Maternity and parental leave regulations 1999. SI 1999 No 3312.); introduced keep-in-touch days allowing work for up to 10 days during maternity leave without losing the right to maternity leave and pay; introduced the right to return to work after full maternity leave on the same terms and conditions, including seniority, pension and similar rights (Reg. 18A of Maternity and parental leave regulations 1999); introduced the right to 26 weeks of additional paternity leave; and extended the right to apply for flexible working to carers of adults.

Family-friendly employment rights have firmly become part of the political strategy to win the votes . In the 2010 general election, all the main political parties made commitments to improve choice and flexibility for parents and extend the right to flexible working to all employees (See Stephenson 2010). In May 2011, the Coalition Government launched the Consultation on modern workplaces (BIS/11/699.

https://www.gov.uk/government/uploads/system/uploads/attachment_data/file/31549/11-699consultation-modern-workplaces.pdf). This included a proposal for a comprehensive reform of maternity, paternity and parental leave and flexible working regulations in order to introduce a more flexible range of measures that would allow parents to share leave and pay entitlements in a manner tailored to their personal circumstances. Following the consultation, the Children and families Act 2014 introduced shared parental leave and shared parental pay , extended the right to request flexible working to all employees and introduced a flexible procedure of dealing with flexible working applications.

The rationale behind the reform was explained in the Consultation document as the need to move away from the highly gendered, inflexible approach to parental leave rights and assumption that the mother must be the primary carer, and achieve involvement of both parents in shared parenting to benefit families, relationships, children, businesses, and wider society (Consultation on modern workplaces, p.11). With regard to flexible working, the Government announced the objective to stimulate cultural change to make flexible working practices the norm to enable all employees to better balance their work, family and personal lives (Consultation on modern workplaces, p.31). 
If we compare the declared rationale behind the Labour Government and the Coalition Government reforms, a clear similarity can be observed in the emphasis on the balance between the interests of all actors in the employment relationship itself and in the wider social and economic contexts. This should not come as a surprise taking into account that the difference between the Conservative governments and New Labour is described as a 'socialdemocratic variant of neo-liberalism' (Hall, 2003, pp. 10-24, 22). On the one hand, the Labour Government made a commitment to supporting working families (McColgan 2000, pp. 125-143). On the other hand, the reform was driven by the view that employment rights facilitate productive and committed workers rather than creating burdens for businesses (Fredman 2004, pp. 299-319). Therefore, critical assessment of the family-friendly reforms under the Labour and Coalition Governments should take into account the socio-economic context which can explain the shortcomings of the regulation.

Although in the North and West European countries, to which the UK belongs, complex households containing relatives outside the nuclear family have almost disappeared, the family responsibilities of caring for adult relatives remain topical. If we look at the familyfriendly reform of employment law in the UK in economic context, the shortage of funds to be allocated for care began even before the economic downturn of 2008. Combined with the growing burden of the needs of the ageing population, the budgetary restrictions have led to the policies in which the family is seen as a natural provider of childcare and care for adults, and sometimes, of financial support. In the UK, the traditional policy of non-interference was quite efficient for relieving the budgetary burden by re-integrating the duty of care into the family. However, the policy of choice and flexibility in the reconciliation of work and family life provides a much more attractive narrative to disguise shifting the burden of care provision from the shoulders of the Government onto the family.

Similarly the family-friendly rhetoric of the Coalition Government cannot be taken at face value. The measures aimed at creation of more choice and flexibility of working arrangements should be seen in the wider context of the austerity welfare cuts and the general commitment of the Conservative Party to the Schumpeterian workfare policy with its emphasis on supporting innovative businesses and subordination of welfare policy to the demands of flexible labour markets and structural competitiveness (Jessop 1992). For example, the need to confirm its commitment to developing businesses, led the Coalition Government to introduce the employee-ownership contracts which allow purchase of employers' shares on the condition of surrendering, among other employment rights, the right to flexible working application. The question which will be explored in the following chapter is whether the current regulation enables parents' and carers' choice and provides them with flexibility, to achieve the objectives proclaimed by the Labour and Coalition Governments.

From family-friendly policy to the family-friendly provisions of employment law: an overstretched flexibility.

Choice and flexibility guaranteed for all or just a few? 
The Children and Families Act 2014 introduced a new entitlement to paid Shared Parental Leave (SPL) that aims to give more choice and flexibility to parents of children born on or after 5 April 2015, alongside the traditional maternity leave. Shared parental leave allows eligible mothers and fathers/partners/adopters to share up to 50 weeks of leave and take it in up to three separate blocks or in one single block. This gives parents choice how much of the SPL each of them will take and when to use it. They can take the leave at the same time or separately (The shared parental leave regulations 2014, SI 2014 No. 3050; The shared parental pay regulations 2014, SI 2014 No. 3051). Does the new entitlement give parents real choice?

The leave provisions intended to give working parents and carers choice and flexibility can become meaningless entitlements due to the corresponding discouraging conditions of pay. As the Equality and Human Rights Commission concluded in their report Working Better published on 30 March 2009, Britain now stands out internationally for having a very long period of leave reserved for mothers, most of it paid at a very low rate. The first 6 weeks are paid at $90 \%$ of weekly earnings, but the rest - at $90 \%$ of weekly earnings or the prescribed weekly rate of statutory maternity pay (merely £139.56 per week from April 2015), whichever is lower. Yet, even that is generous compared with other leave entitlements. Both paternity pay and shared parental pay stand at the lower of $90 \%$ of weekly earnings and the prescribed weekly rate of statutory pay at $£ 139.56$ throughout the entire period of pay. This difference can only encourage choices in favour of the mother taking the traditional maternity leave. That means that the choice based on income considerations can reinforce traditional gender stereotypes of caring responsibilities.

The above conclusion is based on the earlier experience of choices made by parents. There is a clear connection between the uptake of family-friendly leaves by the fathers and the conditions of pay (Lewis and Campbell 2007; James 2009, p. 43). A survey commissioned by the EHRC revealed that $55 \%$ of new fathers took paternity leave to spend time with their newborn and partner. Of the $45 \%$ of new fathers that were unable to take paternity leave, $66 \%$ said they would have liked to, with the most common reason for not doing so was being that they were unable to afford to take the time off (Equality and Human Rights Commission: Working Better: Fathers, family and work - contemporary perspective.

http://www.equalityhumanrights.com/uploaded_files/research/41_wb_fathers_family_and_w ork.pdf). The longer the leave, the more influence the pay makes on the uptake. The TUC analysis found that whereas $91 \%$ of fathers took some leave after childbirth, and $71 \%$ took paternity leave of one or two weeks immediately after the childbirth, only $0.6 \%$ took additional paternity leave in 2011 and 2012 (Eurofoundation 2015).

Does this mean that shared parental leave will not benefit anyone? The leave was partly introduced following the reflection on the rigidity of the conditions attached to additional paternity leave that gave mothers and fathers a formal choice of the parental care roles, but not the flexibility: the father could take additional paternity leave only if the mother returned to work. Moreover, the father's right to additional paternity leave was conditioned on the entitlement of the mother to statutory maternity leave or allowance. The timing was also restrictive: the first 6 months since the birth were reserved for the mother and not to be shared whilst additional paternity leave was to be taken before the child's first birthday. Due to its dependent nature and the inferior conditions of entitlement, APL failed to bring more real 
flexibility into the body of family-friendly provisions of employment law and, as Caracciolo di Torella pointed out, reinforced the idea that fathers are 'secondary partners'(See Caracciolo di Torella 2007, pp. 318, 320).

The experience of additional paternity leave uptake can well be extrapolated to the uptake of shared parental leave. One of the key factors in employees making the decision to take shared leave will be whether or not their employer decides to enhance shared parental pay to a similar level as enhanced maternity pay. Around 76 percent of those surveyed said this would be either relevant or very relevant to their decision to take time away from work (http://www.personneltoday.com/hr/shared-parental-leave-may-trigger-discriminationclaims-from-men/). Yet, the picture of the shared parental leave uptake maybe more complex. Under the Shared Parental Pay Regulations, employers do not have an obligation to offer the same provision of pay for maternity and shared parental leave as these are different entitlements. However, employers have to make the same provision for shared parental pay for men and women to avoid discrimination claims on grounds of sex. The options include offering equally low pay or equally enhanced pay in line with the enhanced maternity pay. The first option means an unintended negative impact of shared parental leave on other entitlements (maternity pay). The second option may be not affordable for employers. Therefore, the likely scenario is re-assertion of inequality of entitlement to pay for both maternity and shared parental leave, depending on the policy and the economic position of the employer. A survey of employers by Personnel Today and XpertHR suggests that most organisations that offer enhanced maternity pay will also offer enhanced pay to parents taking shared leave. Where they had already made the decision to enhance, $75 \%$ said they would mirror the pay offered to mothers. At the same time, it is clear that the regulation of pay reasserts the social split between the wealthy who can afford SPL and poor families who cannot sacrifice their income. Although the Coalition Government estimated the uptake of shared parental leave as low as $2-8 \%$ of eligible parents (Consultation on modern workplaces. Modern workplaces - government response on flexible parental leave - impact assessment. November 2012, p. 27.

https://www.gov.uk/government/uploads/system/uploads/attachment_data/file/82792/121268-modern-workplaces-response-flexible-parental-leave-impact.pdf), according to the research conducted by the law firm Linklaters based on responses from 250 employees working for FTSE100 employers, 62\% showed an interest in taking a period of shared parental leave. As a result, the current regulation of SPL is likely to bring about a social split between parents who can afford it and those who do not, depending on their personal income circumstances and the policy of the employer. That would mean that SPL gives choice and flexibility not to all, but just a few.

\section{No scope for flexibility?}

Despite the magnitude of family-friendly reform under the Labour Government and the revision of practically all family-friendly leave entitlements under the Coalition Government, some areas which require improvement in terms of flexibility remained unchanged. Most disappointingly, this applied to unpaid parental leave. The Coalition Government made only one change and extended the duration of parental leave to 18 weeks per each child which was required by the revised Parental Leave Directive. Yet, more change is needed to make parental leave more attractive, especially for fathers. Due to the unpaid nature of the leave only $10 \%$ of fathers take up the leave compared with $50 \%$ of mothers. With the introduction of longer maternity pay period the uptake of parental leave has further diminished. Related to 
this is a problem that entitlement to unpaid parental leave is very rigid: it should be taken in blocks of at least 1 week with a maximum of 4 weeks a year which makes it particularly unattractive from two perspectives: the loss of income and a wasteful use of entitlement if parents need shorter periods of leave taken more often. The lack of flexibility in how parental leave can be taken and the was well exposed in the Rodway case (South Central Trains LTD $v$ Christopher Rodway [2005] EWCA Civ. 443) where the father tried unsuccessfully to challenge the requirement of the minimum one week duration of leave. The Court of Appeal held that the UK Parental Leave Regulations requirement of taking the leave in blocks of at least one weeks was within the margin of appreciation given to the member states by the Parental Leave Directive. The Coalition Government missed an opportunity to address this issue in the Modern Workplaces Consultation and make unpaid parental leave more flexible.

Further, the reform failed to improve flexibility of using parental leave which is constrained by the notion of "family" itself in the Parental Leave Regulations. The economic and social transformations of the twentieth century led to a plurality of family forms, such as singleparent families, stepfamilies or patchwork families that include children from previous marriages, cohabiting couples, and same-sex couples. The Labour Government's familyfriendly reform showed some signs of the paradigm shift making paternity leave available not only for biological parents, but also a partner who lives with the mother in an enduring relationship (The paternity and adoption leave regulations 2002. SI 2002 No.2788, reg. 1). Also, as the Adoption and children Act 2002 extended joint adoption to unmarried couples who are partners living in an enduring family relationship and to members of a civil partnership, i.e. members of same-sex relationships, such couples became entitled to apply for statutory adoption leave and pay for one of the members and paternity leave and pay for another. However, entitlement to parental leave, remains reserved for only those employees who have legal responsibility for the child, thus cohabiting partners are excluded. This means that in some families there is no choice of care responsibilities, because only one partner is entitled to parental leave.

The reason for the failure to improve flexibility of family-friendly entitlements is the resistance of employers who are concerned about predictability and managing work arrangements as it became clear in the Modern Work Consultation regarding the proposal to remove the restriction on making applications for flexible working arrangements limited to one application in the period of twelve months. The Coalition Government accepted the arguments of businesses. For similar reasons, the Modern Workplace Consultation failed to address the one-way nature of the variation of contract under s. 80F ERA 1996. Under the current provision, the accepted application leads to a permanent variation of contract that can be changed only by making another application in twelve months.

\section{The implications of reflexive regulation.}

The effectiveness of family-friendly entitlements depends, among other factors, on the choice of regulatory tools which, in its turn, is determined by the socio-political context of the reform and wider policy considerations. The regulatory tools that are present in the family- 
friendly provisions of employment law can be characterised as a mixture of prescriptive norms and reflexive regulation. An example of the first type of regulatory tools is the floor of rights regarding conditions of entitlement and duration of leave and respective duration and rates of pay. The second type of regulation falls within the so-called "reflexive regulation" which is associated with the shift from substantive norms to procedural norms, default rules, and other quasi-optional forms of regulation (Deakin 2008, pp. 319-321).

Reflexive legal norms have both advantages and disadvantages regarding their effectiveness for enhancement of the family-friendly rights of employees. On the one hand, they ensure flexibility for employers and employees which means that economically and socially sound consensus can be reached to everyone's satisfaction. On the other hand, they can be criticised for putting in place weak and meaningless entitlements. If we take the example of regulation of parental leave, the employers and employees are encouraged by Maternity and Parental Leave Regulations 1999 to have their own agreements that go beyond the minimum standard guaranteed by Schedule 2 by concluding collective agreements and workforce agreements. Only in the absence of agreement the fall-back statutory provisions apply. This reflects the neo-liberal view of employment relations which rejects the fundamental power imbalance inherent in the employment contract and makes an assumption that employees and employers have to engage in extensive cooperation with each other (Smith and Morton 2006, pp. 401420, 402-403; Collins 2002, pp. 450-469). However, if this vision is incorrect, for the reflexive regulation to be effective, institutions and mechanisms must be in place, and beyond law, to receive and translate reflexive legal norms in a way that ensures their effectiveness, such as collective bargaining or consultation etc. in order to correct the imbalance of the bargaining power between the employer and the employee. In the absence of such mechanisms, reflexive regulation may have serious ramifications: it may lead to inequality in family-friendly entitlements, provide inferior guarantees of rights, and disguise the reluctance or ineffectiveness of state intervention in balancing work and family life.

Perhaps, the most unfortunate development toward deregulation can be observed in the entitlement to flexible working applications. From its introduction by the Labour Government procedural guarantees played an important, though weak role in making this entitlement meaningful (see also Croucher and Kellicher 2005, pp. 503-520). Under The Flexible Working (Procedural Requirements) Regulations 2002 (SI 2002 No. 3207), the employer had a duty to arrange a meeting with the employee, explain the reasons for their decision on the application and to provide the right of appeal with the right to be accompanied to the meetings. However, the Coalition Government replaced the statutory procedure of application for flexible working with the duty of employees to consider the request in a reasonable manner which is explained in the new Acas Code of Practice on Handling in a Reasonable Manner Requests to Work Flexibly. The new procedure does not require the employer to offer an appeal process, even though the Acas Code recommends that such a procedure helps ensure that the application was considered in a reasonable manner. Also, the Acas Code suggests that an employer may want to have a discussion with employees to see if there is any room for adjustment or compromise before coming to the decision (Handling requests in a reasonable manner to work flexibly: an Acas guide. March 2014, p. 15). However, failure to do so does not necessarily compromise the reasonableness of the manner in which the application was considered. As a result, the statutory protection is now limited to the right to apply to an employment tribunal with regard to the compliance of the employer with the 
requirement to consider the application in a reasonable manner and making a decision on the basis of correct facts.

On the one hand, the new regulation offers some guarantees along the principles developed by the Court of Appeal in the Lax case (Hardy and Hansons v Lax [2005] EWCA Civ 846) which requires genuine efforts from employer to accommodate request. The flaws of reflexive regulation can be corrected by the courts, especially where direct discrimination claims can be advanced by the fathers if the employer has a policy of favouring women's applications (Robert Jones v Gan Insurance ET/2000; Walkingshaw v The John Martin Group ET/401126/00, decision of 15 November 2001 discussed in Caracciolo di Torella 2007; Armstrong v DB Regio Tyne and Wear Ltd ET/2500602/11). Also, the seminal Coleman v Attridge case (Case C-303/06, Coleman v Attridge Law [1998] ECR I-00621) emphasised the possibility of discrimination by association claims on grounds of disability. On the other hand, enforcement through individual action can only be the last resort, and, therefore, is not a substitute for effective regulation (See also James 2009, pp. 48-49). It was not surprising that at the Second Reading of the Children and Families Bill 2013 some of the MPs expressed concerns over the replacement of the statutory procedure (HC Deb 25 February 2013 c91).

The questionable effectiveness of family-friendly entitlements implemented through reflexive regulations is also evident in the entitlement to 'keep in touch days' (KIT) introduced by Work and Families Act 2006 to allow mothers to work up to ten days during maternity leave without its termination. The Children and Families Act 2014 introduced a further entitlement for parents to work up to 20 days during Shared Parental Leave (SPLIT days). The clear objective of those provisions is to bring more choice and flexibility to help parents to stay in touch with the employer, but this may not be achieved due to the choice of regulatory tools. The regulations provide no guarantees leaving everything to negotiation between a vulnerable pregnant employee and the employer on the kind of work to be done during 10 days when the employee is allowed to work during maternity leave; the pay; and any other arrangements. In reality, this may mean uncertainty and confusion, as it was already pinpointed by James (James 2007, pp. 315-318; James 2006, pp. 272-278). The use of KIT and SPLIT entitlements is not compulsory, but is it easy to say "no" knowing that on the return from a full maternity leave the same job may not be offered? And how will the refusal affect promotion? Even statutory protection against detriment on grounds of pregnancy under s.47C ERA 1996 may be ineffective as it would be difficult to prove the reason of unfavourable treatment (see The National Union of Teachers $v$ Ms L Watson EAT/0204/06). When is it better to agree the pay for work during KIT/SPLIT days - in advance or later? What if the parties agree on the KIT/SPLIT days, but the circumstances change and the employee no longer can honour the agreement? These are important practical questions that expose the disadvantages of reflexive regulation.

\section{Family friendly or worker and business friendly policy?}

One of the paradoxical facts of work-life balance policy in the UK is the difficulty of accommodating family-friendly provisions within a wider work-life balance agenda. This is evident in the development of the regulation of flexible working. When it was introduced by 
s.47 of the Employment Act 2002, the right to flexible working was aimed at reconciliation of work and family life. Initially, it applied to parents/partners, guardians, and adoptive or foster parents of younger and then older children (The flexible working (eligibility, complaints and remedies) (amendment) regulations 2009 extended the statutory entitlement to those with parental responsibility for children under 17. SI 2009 No. 595), but the Work and Families Act 2006 extended it to carers of adults.

The Coalition Government made a commitment to further improve the flexibility of working arrangements with reconciliation of work and personal life. However, the changes introduced by the government are controversial. Following the government proposal in the consultation on 'Modern Workplaces' the right to request flexible working was extended by the Children and Families Act 2014 to all employees from 30 June 2014. Effectively it has become an employee-friendly, rather than family-friendly entitlement placing parents and carers in competition with other employees. Arguably, the result is family-hostile, rather than family-friendly.

Ironically, the new policy followed the recommendation of the Equality and Human Rights Commission (Equality and Human Rights Commission 2009b, p. 63). On the one hand, it is understandable that not only parents and carers may benefit from flexible working arrangements. Also, flexible arrangements have a positive impact on businesses. As EHRC points out, there is overwhelming evidence that flexible working for all benefits the economy as a whole (Equality and Human Rights Commission 2009c). Therefore, it is important to encourage flexibility of working patterns. However, that does not mean that, as far as the statutory entitlement to request flexible working is concerned, the Government should not have a policy of specific protection of rights of parents and carers whose requests are more likely to be based on the need for flexibility, rather than a choice. In its policy briefing on the rights of parents, EHRC stated that failure to enable flexible working can result in parents, especially mothers being driven out of the labour market. EHRC research into sex discrimination in the financial services industry found that one of the greatest barriers to women's greater participation, equal standing and equal pay in the industry was a culture of long working hours and "presenteeism", the reluctance to provide flexible working arrangements, and pressure on women working flexibly to resume standard and long working hours (see Equality and Human Rights Commission 2010; Equality and Human Rights Commission 2009d).

There is a strong evidence that parents, especially fathers, are in a vulnerable position due to the negative stereotypes attached to flexible working requests, although flexible working arrangements need not mean shorter hours but rather a move away from the rigidity of an office based set hours working day. It is now widely acknowledged that the right to request flexible working is important to parents, in particular fathers, who tend to work longer hours and are less likely to request and be granted flexible working arrangements (see Equality and Human Rights Commission 2009a). The vulnerable position of carers with regard to flexible working applications was highlighted in Coleman $v$ Attridge.

Yet, the policy of extension of the right to flexible working requests to all employees fails to take into account the unintended consequences of this decision. The applications of parents and carers are now less likely to be granted when considered together with other applications for flexible working. According to the Acas Guide, when an employer receives more than one request, they are not required by the law to make value judgements about the most deserving request. An employer should consider each case on its merits looking at the business case and 
the possible impact of refusing the request (Handling requests in a reasonable manner to work flexibly: an Acas guide. March 2014, p. 15). Unless the employers policy is discriminatory, parents and carer's requests have no advantage in competition with other applications. In the absence of a comprehensive and well-thought through flexible working policy adopted by the employer, when an application of a parent is weighed against an application of employees who seek flexibility to pursue their leisure activities, the working environment may easily turn into survival of the fittest. Therefore, unfortunately, the extension of flexible working entitlement to all employees promotes flexible working as a tool to save business costs as part of their strategies for overcoming the constraints of recession, but not as a model to accommodate needs for parents and carers. The only area where family-friendly language remains in the regulation of flexible working requests is the entitlement for parents who return after parental leave to make a variation of contract request, under the Parental Leave Directive 2010/18.

Arguably, the objective of changing stereotypes and making flexible working the norm could have been achieved without weakening the family-friendly character of the right o request flexible working, but rather by developing non-legislative measure to promote flexible working opportunities for all.

\section{Conclusion.}

Overall, the family-friendly reform under the Labour government and the Coalition government has brought about some choice and flexibility helping parents and carers to reconcile their work and family life. However, since the reform was driven not only by concerns about the families' welfare, but also economic efficiency, only some families and carers will be able to fully benefit from the new rights. The combination of the long low-paid maternity leave, short-term low-paid paternity leave, low paid shared parental leave, and unpaid parental leave still re-asserts the stereotype that it is primarily women who are responsible for the care of young children. Therefore, the gender-based work/family balance stereotypes have not yet been sufficiently challenged by the family-friendly reform. Moreover, the reform created a division between wealthy and poor families with regard to affordability of choice and flexibility. The guarantees of family-friendly entitlements are weakened by reflexive? regulation and, finally, the right to flexible working applications has lost its family-friendly purpose.

What does the future hold for the family-friendly reform of employment law in the UK? In the 2015 general election, the family friendly policy was again part of the political campaign. The Labour Party pledged the extension of paternity leave from two to four weeks, raised statutory pay and a consultation on allowing working grandparents to share unpaid parental leave (The Labour Party Manifesto 2015). Liberal Democrats promised to extend shared parental leave with a 'use it or lose it' month for fathers and to introduce paid leave for carers who qualify for Carer's Allowance (Liberal Democrats Manifesto 2015). However, the victory of the Conservative party who did not make any pledges in their Manifesto, means that the likely development of family-friendly policies will be focused on the review of the regulations made under Children and Families Act 2014 which should take place after 2018 
(Explanatory memorandum to the employment rights act regulations 2014, the shared parental leave regulations 2014, and the statutory shared parental pay regulations 2014, para.12.1. http://www.legislation.gov.uk/uksi/2014/3092/pdfs/uksiem_20143092_en.pdf). The outcome of this review will be important for addressing the flaws of the current regulation and making choice and flexibility meaningful for more working parents and carers. It also remains to be seen how the review will be affected by the vote in the UK's in-out EU referendum which should be held by the end of 2017. The exit from the EU would mean that the EU law and the case of the Court of Justice of the European Union will no longer shape UK law and policy on work-life balance. The negative implications may ensue as the UK legislator will not be bound by the provisions of EU law on pay and leave for working parents which enable choice and flexibility in working arrangements. At the same time, its impact of the exit from the EU may be limited due to the fact that the UK work-life balance policy, albeit inspired by the EU, has now taken on a life of its own and has been recognised by all major UK political parties as an important part of policies on economic growth and competitiveness linked to flexible labour markets.

\section{References}

Caracciolo di Torella, E., 2007. New labour, new dads - the impact of family-friendly legislation on fathers. Industrial law lournal, 36 (3), 318-328.

Caracciolo di Torella, E., 2011. Is there a fundamental right to reconciliation of work and family life in the EU? In: N. Busby and G. James, eds. Families, care-giving and paid work: challenging labour law in the $21^{\text {st }}$ century. Chaltenham: Edward Elgar, 52-65.

Caracciolo di Torella, E. and Masselot, A., 2010. Reconciliation of work and family life in EU law and policy. Basingstoke: Palrgrave Macmillan.

Consultation on modern workplaces, 2011 BIS/11/699. https://www.gov.uk/government/uploads/system/uploads/attachment_data/file/31549/11_ 699-consultation-modern-workplaces.pdf

Consultation on modern workplaces, 2012. Modern workplaces - government response on flexible parental leave - impact assessment.

https://www.gov.uk/government/uploads/system/uploads/attachment_data/file/82792/12-

1268-modern-workplaces-response-flexible-parental-leave-impact.p $\overline{\mathrm{df}}$

Collins, H., 2002. Is there a third way in labour law? In: J. Conaghan, R. Fischi and K. Klare, eds. Labour law in the era of globalisation. Oxford: Oxford University Press. 450-469.

Croucher, R. and Kellicher, C., 2005. The right to request flexible working in Britain: the law and organisational realities". The International Journal of Comparative Law and Industrial Relations, 21 (3), 503-530.

Deakin, S., 2008. The regulation of women's pay: from individual rights to reflexive law? In: J. Scott, S. Dex and H. Joshi, eds. Women and employment changing lives and new challenges. Chaltenham: Edward Elgar, 319-321.

Engelen, T., 2003. A transition prolonged: demographic aspects of the European family. In: D.I. Kertzer and M. Barbagli, eds. Family life in the twentieth century. New Haven, London: Yale University Press, 273-310.

Equality and Human Rights Commission, 2009a. Working better: fathers, family and work contemporary perspectives.

http://www.equalityhumanrights.com/uploaded_files/research/41_wb fathers family and work.pdf Equality and Human Rights Commission, 2009b. Working better: meeting the changing needs of 
families, workers and employers in the $21^{\text {st }}$ century.

http://www.equalityhumanrights.com/sites/default/files/publication_pdf/working_better_final_pdf_25 0309.pdf

Equality and Human Rights Commission, 2009c. Working Better - A management guide to flexible working.

http://www.equalityhumanrights.com/uploaded files/Employers/flexbetterworkingguide.pdf.

Equality and Human Rights Commission, 2009d. Financial services inquiry: sex discrimination and gender pay gap report of the Equality and Human Rights Commission,

$\mathrm{http} / / / \mathrm{www}$.equalityhumanrights.com/uploaded files/financial services inquiry report.pdf

Equality and Human Rights Commission, 2010. Policy briefing: EU pregnant workers directive. http://www.equalityhumanrights.com/legal-and-policy/at-the-commission/european-policy/eu-

pregnancy-directive

Fredman, S., 2004. Women at work: the broken promise of flexicurity. Industrial law journal. 33 (4), 299-319.

Hall, S., 2003. New labour's double-shaffle. Soundings, 24.

House of Commons Debates, 2013. 25 February. c91.

James, G., 2006. The work and families act 2006: legislation to improve choice and flexibility? Industrial law journal. 35 (3) 272-278.

James, G., 2007. Enjoy your leave but 'keep in touch': help to maintain parent/workplace relations. Industrial law journal, 36 (3) 315-318.

James, G., 2009. The legal regulation of pregnancy and parenting in the labour market. London: Routledge-Cavendish. 43.

Janssens, A., 2003. Economic transformation, women's work, and family life. In: D.I. Kertzer and M. Barbagli, eds. Family life in the twentieth century. New Haven, London: Yale University Press, 56.

Jessop, B., 1992. The schumpeterian workfare state: or 'on japanism and post-fordism'”. Paper presented at the $8^{\text {th }}$ Conference of Europeanists, Chicago..

Lewis, J. and Campbell, M., 2005. UK work/family balance policies and gender equality 1997-2005. Social policies: international studies in gender, state and society, 14 (1) 4-30.

Lewis, J., 2000. Work-family balance, gender and policy. Chaltenham: Edward Elgar, 10-15.

McColgan, A., 2000. Family-friendly frolics? The maternity and parental leave etc. regulatons 1999. Industrial law journal. 29 (2), 125-143.

Eurofoundation, 2015. Promoting uptake of parental leave and paternity leave among fathers in the European Union. Eurofoundation, Publications Office of the European Union.

Saraceno, C., 2003. Social and family policy. In: D.I. Kertzer and M. Barbagli, eds. Family life in the twentieth century. New Haven, London: Yale University Press, 238.

Segalen, M., 2003. Kinship ties in European families. In: D.I. Kertzer and M. Barbagli, eds. Family life in the twentieth century. New Haven, London: Yale University Press, 350.

Smith, P. and Morton, G., 2006. Nine years of new labour: neoliberalism and workers' rights. British Journal of Industrial Relations. 44 (3), 401-420, 402-403.

Stephenson, M.A., 2010. Fathers, families and work: putting 'working fathers' in the picture. The Political Quarterly, 81. 237.

Liberal Democrats Manifesto 2015. http://www.libdems.org.uk/manifesto.

The Labour Party Manifesto 2015. http://www.labour.org.uk/manifesto.

The White Paper Fairness at Work. May 1998. Cm 3968,

http://webarchive.nationalarchives.gov.uk/+/http:/www.berr.gov.uk/files/file24436.pdf)

Weldon-Johns, M., 2013. EU Work-Family Policies_Challenging Parental Roles or Reinforcing Gendered Stereotypes? European law journal, 19 (5). 662-681. 
